\title{
ANTI-BIOFILM ACTIVITY EVALUATION AND MOLECULAR DOCKING STUDY OF SOME 2(3-PYRIDYL)-THIAZOLYL-1,3,4- OXADIAZOLINES
}

\author{
CĂTĂLIN ARANICIU ${ }^{1}$, OVIDIU ONIGA ${ }^{2}$, GABRIEL MARC $^{2 *}$, MARIANA DOINA PALAGE ${ }^{1}$, \\ LUMINIȚA MĂRUȚESCU ${ }^{3,4}$, MARIANA CARMEN CHIFIRIUC ${ }^{3,4}$, CRISTINA IOANA STOICA ${ }^{1}$, \\ IOANA IONUȚ ${ }^{2}$, SMARANDA DAFINA ONIGA ${ }^{1}$ \\ 1 "Iuliu Hațieganu” University of Medicine and Pharmacy, Faculty of Pharmacy, Department of Therapeutic Chemistry, 12 Ion \\ Creangă Street, 400010, Cluj-Napoca, Romania \\ 2 "Iuliu Hațieganu” University of Medicine and Pharmacy, Faculty of Pharmacy, Department of Pharmaceutical Chemistry, 41 \\ Victor Babeș Street, 400012, Cluj-Napoca, Romania \\ ${ }^{3}$ University of Bucharest, Faculty of Biology, Department of Microbiology, 1-3 Portocalelor Street, 60101, Bucharest, Romania \\ ${ }^{4}$ Research Institute of the University of Bucharest - ICUB, 91-95 Independenței Street, Bucharest, Romania
}

*corresponding author: Marc.Gabriel@umfcluj.ro

Manuscript received: March 2018

\begin{abstract}
Among the most promising unconventional targets for the development of new antimicrobial drugs is bacterial adherence and biofilm formation. This study is focused on the evaluation of a series of 2(3-pyridyl)-thiazolyl-1,3,4-oxadiazolines as bacterial biofilm inhibitors against a panel of Gram-positive bacterial strains. Some of these compounds showed interesting activity against biofilm formation of the Staphylococcus aureus strain. A preliminary study of the mechanism of action was carried out by a molecular docking assay between the compounds and the Sortase A enzyme. The connection between the docking results obtained and the anti-biofilm activity suggested that the tested compounds could have as potential mechanism of action the inhibition of Sortase A.
\end{abstract}

\section{Rezumat}

Printre cele mai promițătoare ținte neconvenționale pentru dezvoltarea de noi medicamente antimicrobiene se numără aderența bacteriană și formarea biofilmului bacterian. Acest studiu s-a concentrat pe evaluarea unei serii de 2(3-piridil)tiazolil-1,3,4-oxadiazoline ca inhibitori ai formării biofilmului bacterian împotriva unui grup de tulpini bacteriene Grampozitive. Unii dintre acești compuși au prezentat o activitate interesantă împotriva formării biofilmului asupra tulpinii de Staphylococcus aureus. Un studiu preliminar al mecanismului de acțiune a fost efectuat printr-un test de andocare moleculară între compuși și enzima Sortaza A. Conexiunea dintre rezultatele de andocare moleculară obținute și activitatea anti-biofilm a sugerat că acești compuși ar putea avea ca mecanism potențial de acțiune inhibarea Sortazei A.

Keywords: anti-biofilm activity, sortase A, thiazolyl-1,3,4-oxadiazolines

\section{Introduction}

The remarkable ability of bacteria to develop resistance to antimicrobial agents is a pressing concern for public health. One of the most important reasons for the failure of antimicrobial therapy is the formation of microbial biofilms [5, 6, 10, 43]. A microbial biofilm is a structured community of microorganisms embedded in a self-secreted polymeric matrix, adherent to an inert or living surface $[14,15]$. Microorganisms growing in a biofilm are highly resistant to antimicrobial agents due to many phenotypic mechanisms $[6,11,14]$. Cell surface proteins of Gram-positive bacteria play various important roles in pathogenicity. A major mechanism for the surface display of proteins, by Gram-positive bacteria, is sortase-mediated covalent attachment to the cell wall $[20,22]$. Bacterial sortases are cysteine transpeptidases regulating the secretion and anchoring of many cell wall proteins with significant roles in bacterial adhesion and invasion of host tissues, biofilm formation, and immune evasion by inhibition of opsonisation and phagocytosis [7, 37].

The Sortase A (SrtA) enzyme from $S$. aureus is a prototypical member of the sortase family. $S$. aureus strains lacking the SrtA gene are unable to retain and display LPxTG proteins at the cell surface. As a consequence, SrtA mutant strains are defective in the establishment of acute infections [23].

Several studies have shown that the loss of sortase reduced biofilm phenotype in S. aureus [29], and the mutation of SrtA in S. gordonii also led to decreased biofilm formation [28]. An anti-virulence strategy based on agents that target virulence determinants could be effective in preventing the biofilm formation of Grampositive bacteria $[9,35]$. 
The purpose of the present work was to evaluate the anti-biofilm activity of some previously reported pyridil-thiazolyl-oxadiazolines derivatives [31]. We considered that this structural scaffold could have anti-biofilm activity as it contains structural similarities with other anti-biofilm compounds [16, 24, 25, 33, 38]. Also, the pyridil-thiazolyl-oxadiazoline series complies with the general requirements for a good SrtA inhibitor, as they have been described by Nițulescu et al. [27]. These compounds were formerly tested as direct acting antimicrobial agents but the results showed a low antimicrobial activity with high MIC values. The spectrum comprised particularly Gram-positive bacterial strains, as shown in our previous paper [31].

Despite the high MIC values obtained for these compounds, we decided to test them for their antibiofilm activity against Gram-positive bacteria, taking into account that, in many cases, the sub-inhibitory concentrations of the antimicrobial substances could interfere with the expression of different virulence features, such as adhesins or toxins [3, 4, 17]. The absence of antibacterial activity may have some benefits, by reducing the selective pressure against biofilm formation, thus decreases the likelihood of resistance development [18].

In order to provide a possible mechanism for the antibiofilm activity, we performed a molecular docking study of the biologically active compounds to estimate their potential ability to inhibit the key enzyme for the anchoring of microbial adhesion proteins.

\section{Materials and Methods}

The structures of the tested compounds:

The structures of the tested compounds are presented in Figure 1.
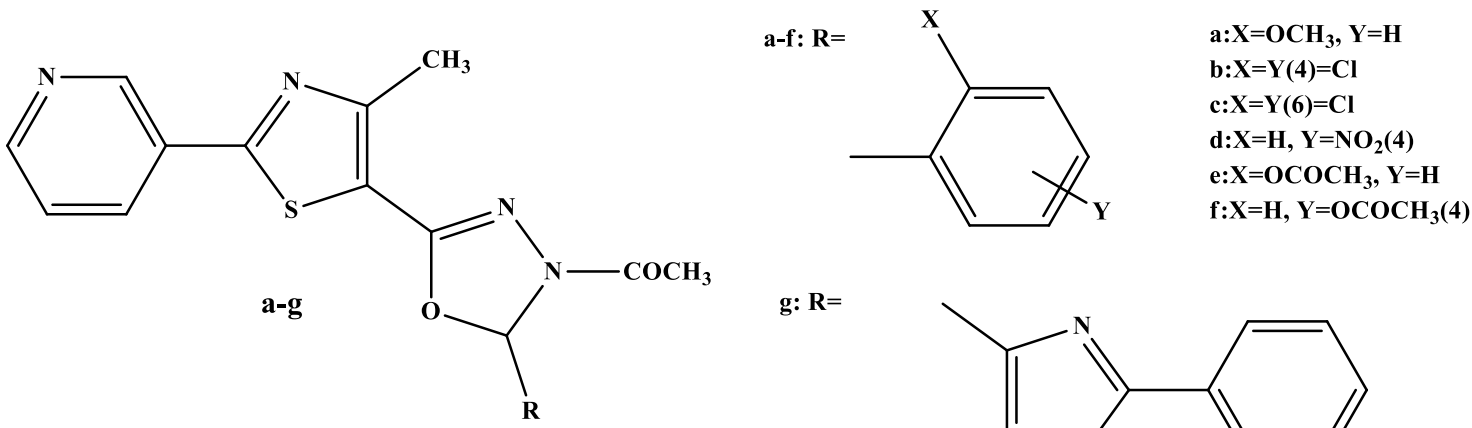

g: $\mathbf{R}=$

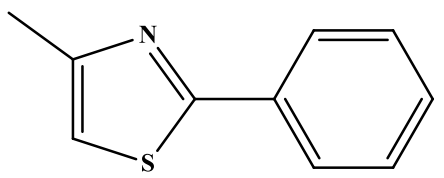

Figure 1.

Structures of the pyridyl-thiazolyl-oxadiazolines derivatives a-g

These compounds were previously synthesized and characterized by our research group [31]. The chemical synthesis involved two steps: condensation of the 4methyl-2-(pyridin-3-yl)-thiazole-5-carbohydrazide with aromatic or heteroaromatic aldehydes to obtain the corresponding Schiff bases followed by the cyclisation of the latter with acetic anhydride to give the pyridyl-thiazolyl-oxadiazolines [31]. Study of the influence of the tested compounds on the microbial ability to colonize the inert substratum and to form biofilms

Chemical reagents and nutrient broths were purchased from Sigma-Aldrich (Taufkirchen, Germany). The microbial strains used were obtained from the collection of the Department of Microbiology, Faculty of Biology from University of Bucharest, Romania. All chemical reagents were of analytical reagent grade purity.

The anti-biofilm activity of the tested compounds was evaluated by the microtiter method $[1,32]$. Initial stock solutions, of $1 \mathrm{mg} / \mathrm{mL}$ in dimethyl sulfoxide DMSO, were prepared for every compound. Two-fold serial dilutions of the compounds solutions (ranging between $1000 \mu \mathrm{g}$ and $2 \mu \mathrm{g} / \mathrm{mL}$ ) were performed in a $200 \mu \mathrm{L}$ volume of liquid nutrient broth/Yeast Extract-Peptone-
Glycerol (YPG) medium, and each of the 96-wells was seeded with $50 \mu \mathrm{L}$ microbial inoculum.

At the end of the incubation period $\left(24 \mathrm{~h}\right.$ at $\left.37^{\circ} \mathrm{C}\right)$, the plastic wells were emptied, washed three times with phosphate buffered saline (PBS), fixed with cold methanol $80 \%$ and stained with $1 \%$ violet crystal solution for 15 minutes.

The biofilm formed on the plastic wells was resuspended in 33\% acetic acid solution. Cell density was measured by reading the optical density of the coloured solution at $490 \mathrm{~nm}$.

The last concentration of the tested compound that inhibited the development of microbial biofilm on the plastic wells was considered the minimal biofilm eradication concentration (MBEC) and was expressed in $\mu \mathrm{g} / \mathrm{mL}$.

Molecular docking study

In order to predict the binding affinity of the compounds to SrtA and to evaluate the possible interactions, a molecular docking study was carried out using AutoDock 4.2 [26].

Preparation of targets and ligands for the molecular docking study was performed based on our previous reported protocol $[19,39]$. SrtA (PDB: 2KID, obtained 
FARMACIA, 2018, Vol. 66, 4

by X-ray diffraction) isolated from Staphylococcus aureus was chosen as target in our study. The crystal structure of the protein was taken from Protein Data Bank. The binding site analysis was performed using DoGSiteScorer [44].

With the use of AutoDock Tools [26], water molecules were removed, polar hydrogen atoms were added, nonpolar hydrogen atoms were merged, rotatable bonds were defined, amide bonds were set non-rotatable, carboxylic moieties were deprotonated and Gasteiger partial charges were assigned. The search box was defined as $\mathrm{x}=\mathrm{y}=\mathrm{z}=75 \AA \AA$ in dimension centre coordinates set to $\mathrm{x}=-1.072, \mathrm{y}=0.299, \mathrm{z}=4.632$. Grid maps were generated using AutoGrid 4 with 0.375 grid point's size space.

For each compound AutoDock searched for 50 conformers, further grouped them in clusters with $2 \AA$ cluster tolerance. Using BLASTP we found that the catalytic triad from the active site of 2KID is composed of His120, Cys184 and Arg197 [2].

Calculation of the resulted inhibition constants was performed on the basis of the previous reported protocol [39].

\section{Results and Discussion}

Structure of the compounds

The compounds shown in Figure 1 were chosen to be tested as SrtA inhibitors and anti-biofilm agents in view of the fact that their structures are related to the pharmacophore model for SrtA inhibitors proposed by Uddin et al. [42] and Nițulescu et al. [27]: small molecules with a molecular weight between 180 and 600 , with a low molecular flexibility, a number of hydrogen accepting bonding greater or equal to 2 , but not higher than 7 and minimum two hydrophobic centres. The structures are also in agreement with the Bemis-Murcko scaffolding (Figure 2) results obtained by the analysis of 156 small compounds that are known inhibitors of SrtA [27].

They have a scaffold characterized by four or five aromatic rings linked directly, which allows for limited free rotation of the bonds, as shown in Figure 2. The presence of 4 or less rotatable ensures low molecular flexibility, thus complying with the most relevant descriptor for SrtA affinity.

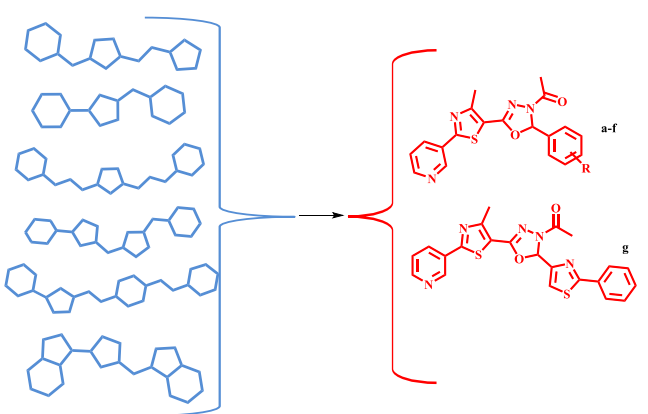

Figure 2.

The results of the Bemis-Murcko scaffolding

\section{Biological evaluation}

\section{Anti-biofilm activity}

Biofilm formation was used as a measure of SrtA inhibition potential, as it is generally accepted that biofilm formation is strictly dependent on the many molecules anchored by sortases at the surface of the cells.

The anti-biofilm activity evaluation was performed against Gram-positive bacterial strains. The compounds were investigated concerning their efficiency against the adherence of cells grown in biofilms developed in plastic wells for three Gram-positive bacterial strains: B. subtillis ATCC 6683, E. faecium E5 and S. aureus ATCC 6538.

The results are presented in Table I.

Table I

Results of the quantitative assay of the influence of the tested compounds on the adherence ability and biofilm development on inert substratum (MBEC $\mu \mathrm{g} / \mathrm{mL}$ and $\mu \mathrm{M} / \mathrm{mL}$ )

\begin{tabular}{|c|c|c|c|c|c|c|}
\hline \multirow{2}{*}{ Compound } & \multicolumn{7}{|c|}{ Microbial strain } \\
\cline { 2 - 7 } & \multicolumn{2}{|c|}{ B. subtillis ATCC 6683 } & \multicolumn{2}{c|}{ E. faecium E5 } & \multicolumn{2}{c|}{ S. aureus ATCC 6538 } \\
\cline { 2 - 7 } & $\mu \mathrm{g} / \mathrm{mL}$ & $\mu \mathrm{M} / \mathrm{mL}$ & $\mu \mathrm{g} / \mathrm{mL}$ & $\mu \mathrm{M} / \mathrm{mL}$ & $\mu \mathrm{g} / \mathrm{mL}$ & $\mu \mathrm{M} / \mathrm{mL}$ \\
\hline $\mathbf{a}$ & 125 & 0.318 & $>1000$ & $>2.538$ & 15 & 0.038 \\
\hline $\mathbf{b}$ & 250 & 0.579 & $>1000$ & $>2.315$ & 7.5 & 0.017 \\
\hline $\mathbf{c}$ & 250 & 0.579 & $>1000$ & $>2.315$ & 15 & 0.034 \\
\hline $\mathbf{d}$ & 250 & 0.611 & $>1000$ & $>2.445$ & 31 & 0.075 \\
\hline $\mathbf{e}$ & 250 & 0.592 & $>1000$ & $>2.367$ & 15 & 0.035 \\
\hline $\mathbf{f}$ & 250 & 0.592 & $>1000$ & $>2.367$ & 125 & 0.296 \\
\hline $\mathbf{g}$ & 250 & 0.559 & $>1000$ & $>2.237$ & 62.5 & 0.139 \\
\hline
\end{tabular}

Regarding the anti-biofilm activity, results showed a difference between various bacterial strains. As such, the compounds are totally inactive in preventing $E$. faecium E5 biofilm formation, while having a rather modest effect against B. subtillis ATCC 6683 biofilm. However, a good activity was noticed against S. aureus ATCC 6538 biofilm formation.
The difference in activity against various Gram-positive strains is typical and consistent with results from other research $[3,4,16,25,30]$. Although SrtA is present in all Gram-positive bacteria, it is important to remember that, despite their structural similarities, these enzymes can vary greatly from one strain to another [37]. A phylogenetic analysis [12] revealed that SrtA from $S$. 
FARMACIA, 2018, Vol. 66, 4

aureus is closely related with that of $S$. epidermidis, but shares fewer similarities with enterococcal or bacillus SrtA. As a result, the structural difference in SrtA active site can translate in a disparity of biological activity for new anti-biofilm agents [30].

Also, the process of biofilm formation is very complex and involves an array of mechanisms. Studies have indicated that in some microbes the loss of 1 mechanism (e.g. SrtA) can trigger the compensatory activation of secondary mechanisms that compensate for its biofilm formation role [13]. Also, in some bacterial strains biofilm development can be mediated primarily by other mechanism like the ones involving sortase $\mathrm{C}$ or B $[13,36]$.

The results showed a more intense anti-biofilm activity as compared to the antimicrobial activity for the tested compounds [31]. Thus, despite their high MICs, the tested substances seem to be promising as potential anti-pathogenic agents, alternative or complementary to conventional antibiotics in the treatment of infections caused by this pathogen under biofilm form.

In view of the results obtained for planktonic growth inhibition [31], we can assume that the effect of the compounds on biofilm formation is not related to their biocidal activity. These types of compounds could target the early steps of bacterial adhesion, essential for the establishment of infections and colonization, without affecting the bacterial growth, imposing a low selection pressure and thus, avoiding development of resistance [18].

Molecular docking study

In order to investigate the potential anti-biofilm mechanism, we focused on SrtA, the key enzyme that regulates the anchoring of adhesion proteins in Grampositive bacteria (e.g. S. aureus), as possible target for our molecules.

SrtA is a membrane enzyme responsible for the anchoring of surface-exposed proteins to the cell wall

envelope of Gram-positive bacteria and plays a critical role in the bacterial pathogenesis by promoting virulence mechanisms such as: adhesion to host tissues, evasion of host defences and biofilm formation [8]. The active site of enzymes belonging to the sortase family has three amino acids residues: His120, Cys184 and Arg197. Their catalytic significance has been well established: any substitutions of these amino acids results in complete loss of the enzymatic activity [21, 41]. Other crucial residues are represented by: Val168, Leu169, Ala104, Ala118 and Leu97 [40].

Three dimensional analysis of bacterial SrtA reviewed its triangular -" $\Psi "$ " shaped active site, with three pockets close to each other in the inner region of the active site and opposite to them, one larger pocket allowing the access of the substrate as shown in Figure 3 [21].

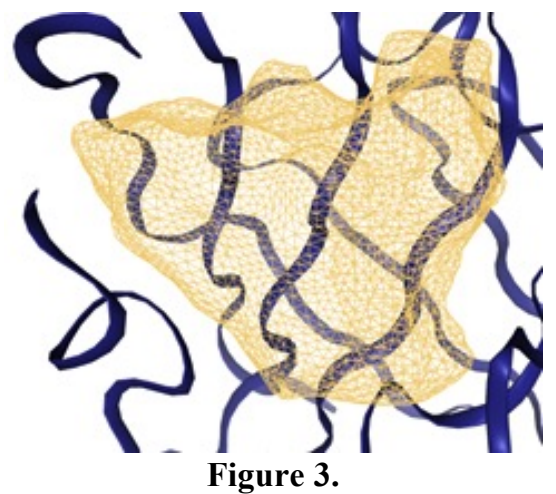

Accessible volume in the catalytic site of SrtA (2KID)

Compounds a-f were docked into the active site of SrtA. The predicted binding affinity of these compounds to the active site of the target enzyme, their $2 \AA$ cluster of conformations analysis and the inhibition constant (ki) of the best pose are presented in Table II.

Table II

Molecular docking results for the compound a - g

\begin{tabular}{|c|c|c|c|c|}
\hline \multirow{2}{*}{ Compound } & \multicolumn{4}{|c|}{ SrtA (2KID) } \\
\cline { 2 - 5 } & $\begin{array}{c}\text { Binding affinity } \\
(\mathrm{kcal} / \mathrm{mol})\end{array}$ & $\begin{array}{c}\text { Inhibition constant } \\
(\mu \mathrm{M})\end{array}$ & $\begin{array}{c}\text { Conformations in the } \\
\text { cluster }\end{array}$ & $\begin{array}{c}\text { Mean binding energy in the cluster } \\
(\mathrm{kcal} / \mathrm{mol})\end{array}$ \\
\hline $\mathbf{a}$ & -7.57 & 2.84 & $40 / 50$ & -7.38 \\
\hline $\mathbf{b}$ & -8.54 & 0.55 & $45 / 50$ & -8.50 \\
\hline $\mathbf{c}$ & -8.11 & 1.13 & $44 / 50$ & -8.06 \\
\hline $\mathbf{d}$ & -8.35 & 0.76 & $18 / 50$ & -7.90 \\
\hline $\mathbf{e}$ & -8.27 & 0.86 & $32 / 50$ & -8.06 \\
\hline $\mathbf{f}$ & -7.95 & 1.48 & $17 / 50$ & -7.54 \\
\hline $\mathbf{g}$ & -9.20 & 0.18 & $19 / 50$ & -9.01 \\
\hline
\end{tabular}

Concerning our molecular docking study, results showed that compounds a, b, c and e have very similar interacting conformations (Figure 4) with the binding site of SrtA (2KID).

The binding mode estimated for our compounds is in agreement with the interactions proposed for other small molecules which act as SrtA inhibitors $[8,34]$. 


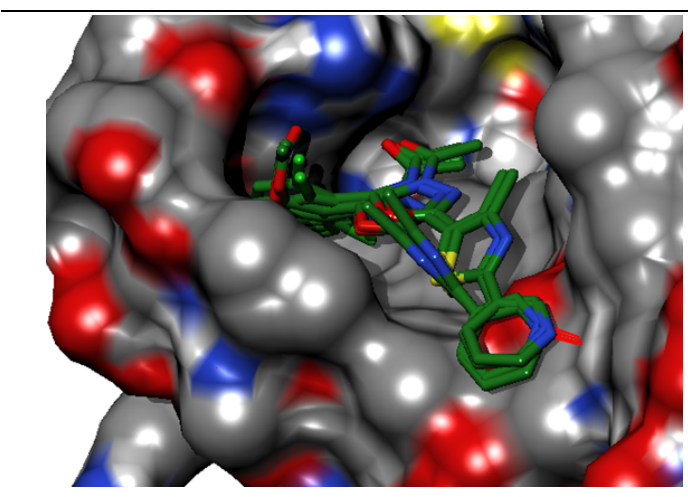

Figure 4.

The predicted binding mode of compounds $\mathbf{a}, \mathbf{b}, \mathbf{c}$ and $\mathbf{e}$ in SrtA binding pocket (surface representation)
Compound $\mathbf{b}$ showed the highest inhibitory capacity of bacterial SrtA, with a $-8.50 \mathrm{kcal} / \mathrm{mol}$ mean binding energy and 45 conformations out of 50 predicted in a 2 Á RMSD cluster tolerance. The interactions of this compound with the amino acids of the SrtA are depicted in Figure 5. The acetyl group from the oxadiazoline ring interacts with Arg197 (an amino acid from the catalytic active site of SrtA) and the aromatic rings fit well into the lipophilic pocket formed between Val166-Lys162, Val168-Leu169 and Leu181-Thr183. The nitrogen from the pyridine ring has a polar contact with the peptide bridge Glu105-Glu106. The other interactions with the binding site are hydrophobic interactions involving, with Val166, Gly167, Val168, Leu169, Ile182, Ile117, Phe103, Gly90 and Ala104.

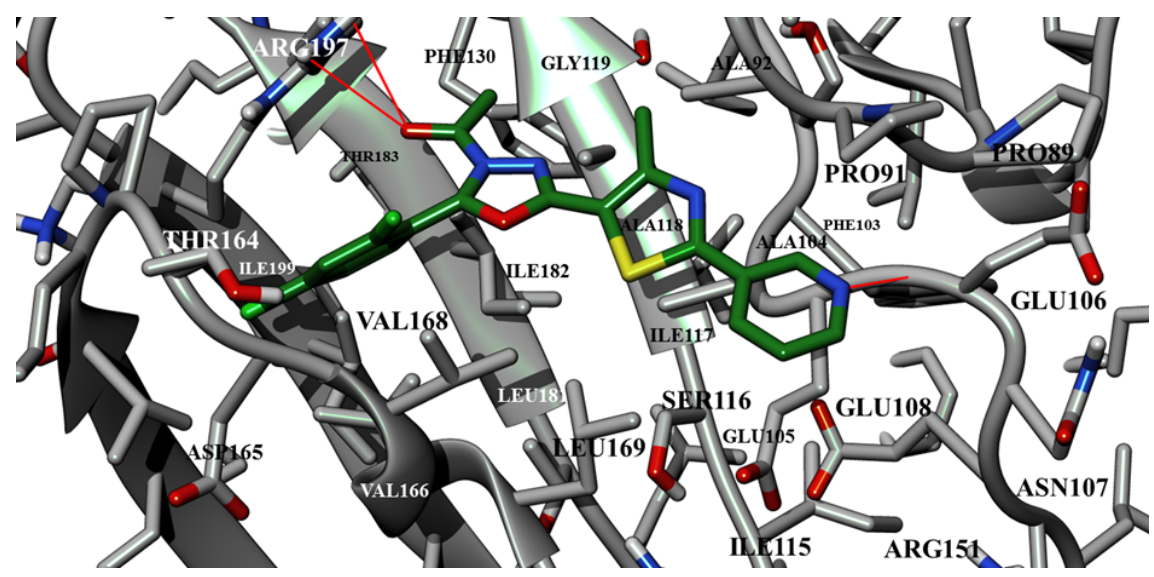

Figure 5.

The predicted binding mode of compound $\mathbf{b}$ in SrtA binding pocket (amino acids residues representation)

A significantly different binding site interaction is shown for the longer compounds such as $\mathbf{d}$ (with a nitro group in the para position of the phenyl ring), f (with an acetyl group in the para position of the phenyl ring) and $\mathbf{g}$ (the compound with five rings directly linked). These structural particularities led to different type of interactions with the active site of the enzyme. Thus, even if these compounds have good binding affinity and inhibition constant values, due to the binding conformation within the enzyme's active site, the interaction with Arg197 is not possible (Figure 6). The lack of interaction with Arg197, a key amino acid from the catalytic active site, could be responsible for a decreased antibiofilm activity, as shown in the MBEC results (Table I).

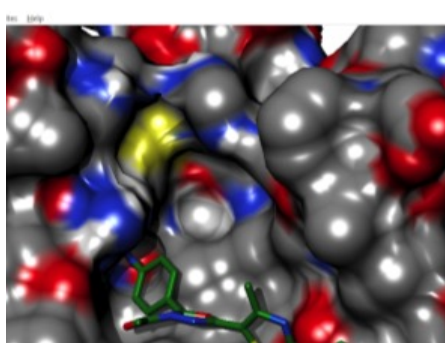

Figure 6
Compound $\mathbf{f}$, for example, has two polar interactions: the nitrogen atom from the oxadiazole ring interacts with the Ala104-Glu105 peptide bond, while the terminal acetyl moiety interacts with the Asn107-
Glu108-Ser109 peptide bonds. The other links with the binding site are represented by hydrophobic interactions with Val166, Gly167, Val168, Leu169, Ile182, Ile117, Phe103, Gly90 and Ala104 residues (Figure 7). 


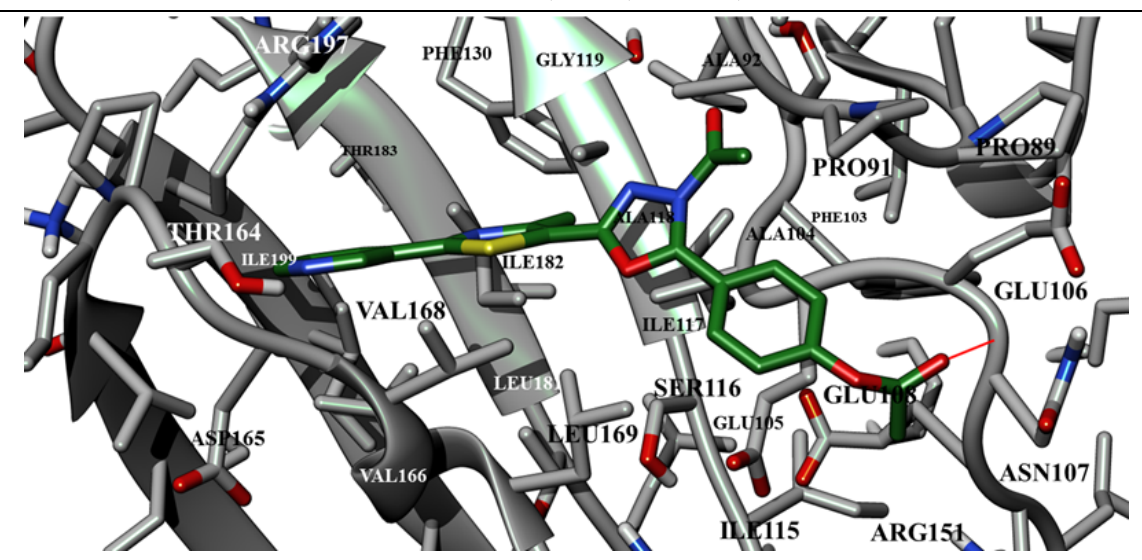

Figure 7.

The predicted binding mode of compound $\mathbf{f}$ in SrtA binding pocket (amino acids residues representation)

Considering the overall trend of the $S$. aureus ATCC $6538 \mathrm{MBEC}$ values and binding affinity predictors values it is apparent that there are some discrepancies between the in silico estimated binding potential and the in vitro result. However, this can be explained by the fact that binding to SrtA does not immediately translate in inhibition of SrtA. This is true especially in case of compounds that potentially bind to the active site in a manner that does not affect the activity of or access to the catalytic triad (as is the case of compounds $\mathbf{d}, \mathbf{f}, \mathbf{g})$. When considering compounds $\mathbf{a}, \mathbf{b}, \mathbf{c}, \mathbf{e}$, that potentially inhibit the catalytic triad, MBEC values show a better anti-biofilm activity.

Furthermore, the differences between the biological activity versus binding affinity of the compounds could be explained by differences in the ability to penetrate biological formations in order to reach the active site of the target macromolecule.

\section{Conclusions}

A series of 2(3-pyridil)-thiazolyl-1,3,4-oxadiazolines were tested for their anti-biofilm activity against several Gram-positive bacterial strains. The results showed a good activity against $S$. aureus biofilm formation, while being virtually inactive against $B$. subtillis and E. faecium. In order to investigate the mechanism of action of these molecules, we performed a molecular docking study against $S$. aureus SrtA. Docking results showed that the investigated series of compounds potentially interact with the active site of SrtA in two major ways. Compounds $\mathbf{d}$, $\mathbf{f}$ and $\mathbf{g}$, although having good binding affinity, interact with the SrtA active site in a manner that does not inhibit the catalytic triad. This predicted binding mode is in agreement with the anti-biofilm activity results for these compounds (e.g. higher MBEC values). A second potential binding mode, displayed by compounds $\mathbf{a}, \mathbf{b}$, $\mathbf{c}$ and $\mathbf{e}$, involves direct interaction with and inhibition of the SrtA catalytic triad. As a result, these types of compounds have better anti-biofilm activity, as proved by MBEC values.

\section{References}

1. $* * *$ Clinical and Laboratory Standards Institute, 2012; 32: 3 .

2. Altschul SF, Madden TL, Schaffer AA, Zhang J, Zhang Z, Miller W, Ligman DJ, Gapped BLAST and PSIBLAST: a new generation of protein database search programs. Nucleic Acids Res., 1997; 25(17): 3389-3402.

3. Araniciu C, Măruțescu L, Oniga S, Oniga O, Chifiriuc $\mathrm{MC}$, Palage MD, Evaluation of the antimicrobial and anti-biofilm activity of some 4,2 and 5,2 Bisthiazoles Derivatives. Dig J Nanomater Bios., 2014; 9: 123-131.

4. Araniciu C, Oniga S, Oniga O, Palage M, Chifiriuc MC, Măruțescu L, Antimicrobial and anti-pathogenic activity evaluation of some 2-(Trimethoxyphenyl)-4Ar1-5-R2-thiazoles. Farmacia, 2015; 63(1): 40-45.

5. Bjarnsholt T, Alhede M, Alhede M, Eickhardt-Sørensen SR, Moser C, Kühl M, Jensen PØ, Høiby N, The in vivo biofilm. Trends Microbiol., 2013; 21: 466-474.

6. Bjarnsholt T, Ciofu O, Molin S, Givskov M, Høiby $\mathrm{N}$, Applying insights from biofilm biology to drug development - can a new approach be developed?. Nature Rev Drug Discov., 2013; 12: 791-808.

7. Bradshaw WJ, Davies AH, Chambers CJ, Roberts AK, Shone CC, Acharya KR, Molecular features of the sortase enzyme family. FEBS J., 2015; 282: 2097-2114.

8. Cascioferro S, Raffa D, Maggio B, Raimondi MV, Schillaci D, Daidone G, Sortase A Inhibitors: Recent Advances and Future Perspectives. J Med Chem., 2015; 58: 9108-9123.

9. Cascioferro S, Schillaci D, Totsika M, Sortase A: An Ideal Target for Antivirulence Drug Development. Microbial Pathogenesis, 2014; 77: 105-112.

10. Chadha T, Bacterial Biofilms: Survival Mechanisms and Antibiotic Resistance. J Bacteriol Parasitol., 2014; 5: 190-194.

11. Chen M, Yu Q, Sun H, Novel Strategies for the Prevention and Treatment of Biofilm Related Infections. Int J Mol Sci., 2013; 14: 18488-18451.

12. Dramsi S, Trieu-Cuot P, Bierne H, Sorting sortases: A nomenclature proposal for the various sortases of Grampositive bacteria. Res. Microbiol., 2005; 156: 289-297.

13. Dunny G, Hancock L, Shankar N, Enterococcal Biofilm Structure and Role in Colonization and Disease. In Enterococci: from Commensals to Leading Causes of Drug Resistant Infection; Gilmore M, Clewell D, Ike Y, 
FARMACIA, 2018, Vol. 66, 4

Eds., Massachusetts Eye and Ear Infirmary: Boston, MA, USA, 2014.

14. Fuente-Núñez C, Reffuveille F, Fernández L, Hancock $\mathrm{RE}$, Bacterial biofilm development as a multicellular adaptation: antibiotic resistance and new therapeutic strategies. Curr Opin Microb., 2013; 16: 580-589.

15. Kostakioti M, Hadjifrangiskou M, Hultgren SJ, Bacterial biofilms: development, dispersal, and therapeutic strategies in the dawn of the postantibiotic era. Cold Spring Harb Perspect Med., 2013; 1: 1-23.

16. Kumar RN, Mallareddy G, Nagender P, Rao PS, Poornachandra Y, Ranjithreddy P, Kumar CG, Narsaiah $\mathrm{B}$, Synthesis of novel triazole functionalized pyridine derivatives as potential antimicrobial and anti-biofilm agents. Ind J Chem., 2016; 55B: 1361-1373.

17. Limban C, Măruțescu L, Chifiriuc MC, Synthesis, Spectroscopic Properties and Antipathogenic Activity of New Thiourea Derivatives. Molecules, 2011; 16: 7593-7607.

18. Maggio B, Raffa D, Raimondi MV, Cascioferro S, Plescia F, Schillaci D, Cusimano MG, Leonchiks A, Zhulenkovs D, Basile L, Daidone G, Discovery of a New Class of Sortase A Transpeptidase Inhibitors to Tackle Gram-Positive Pathogens: 2-(2-Phenylhydrazinylidene)alkanoic Acids and Related Derivatives. Molecules, 2016; 21(241): 1-14.

19. Marc G, Ionuț I, Pirnau A, Vlase L, Vodnar DC, Duma $\mathrm{M}$, Tiperciuc B, Oniga O, Microwave assisted synthesis of 3,5-disubstituted thiazolidine-2,4-diones with antifungal activity. Design, synthesis, virtual and in vitro antifungal screening. Farmacia, 2017; 65(3): 414-422.

20. Maresso AW, Schneewind O, Sortase as a target of antiinfective therapy. Pharmacol Rev., 2008; 60: 128-141.

21. Marraffini LA, Ton-That H, Zong Y, Narayana SV, Schneewind O, Anchoring of Surface Proteins to the Cell Wall of Staphylococcus aureus: a conserved arginine residue is required for efficient catalysis of sortase A. J Biolog Chem., 2004; 279(36): 3776337770 .

22. Marraffini LA, DeDent AC, Schneewind O, Sortases and the Art of Anchoring Proteins to the Envelopes of Gram-Positive Bacteria. Microb Mol Bio Reviews, 2006; 70(1): 192-221.

23. Mazmanian SK, Liu G, Jensen ER, Lenoy E, Schneewind O, Staphylococcus aureus sortase mutants defective in the display of surface proteins and in the pathogenesis of animal infections. Proc Natl Acad Sci USA, 2000; 97: 5510-5515.

24. Mohammad H, Cushman M, Seleem MN, Antibacterial Evaluation of Synthetic Thiazole Compounds In Vitro and In Vivo in a Methicillin-Resistant Staphylococcus aureus (MRSA) Skin Infection Mouse Model. Plos One, 2015; 10: 1-13.

25. Mohammad H, Mayhoub AS, Cushman M, Seleem $\mathrm{MN}$, Anti-biofilm activity and synergism of novel thiazole compounds with glycopeptide antibiotics against multidrug-resistant staphylococci. $J$ Antibiot., 2015; 68(4): 259-266.

26. Morris GM, Huey R, Lindstrom W, Sanner MF, Belew RK, Goodsell DS, Olson AJ, AutoDock4 and AutoDockTools4: Automated Docking with Selective Receptor Flexibility. J Comput Chem., 2009; 30(16): 2785-2791.
27. Nitulescu G, Zanfirescu A, Olaru OT, Nicorescu IM, Nitulescu GM, Margina D, Structural Analysis of Sortase A Inhibitors. Molecules, 2016; 21(11): 1591.

28. Nobbs A, Vajna RM, Johnson JR, Zhang Y, Erlandsen SL, Oli MW, Kreth J, Brady LJ, Herzberg MC, Consequences of a sortase A mutation in Streptococcus gordonii. Microbiology, 2007; 153: 4088-4097.

29. O’Neill E, Pozzi C, Houston P, Humphreys H, Robinson DA, Loughman A, Foster TJ, O'Gara JP, A novel Staphylococcus aureus biofilm phenotype mediated by the fibronectin-binding proteins, FnBPA and FnBPB. $J$ Bacteriol., 2008; 190: 3835-3850.

30. Oniga SD, Araniciu C, Palage MD, Popa M, Chifiriuc MC, Marc G, Pirnau A, Stoica CI, Lagoudis I, Dragoumis T, Oniga O, New 2-Phenylthiazoles as Potential Sortase A Inhibitors: Synthesis, Biological Evaluation and Molecular Docking. Molecules, 2017; 22: 1-18.

31. Oniga SD, Araniciu C, Stoica CI, Palage MD, Vlase L Pîrnău A, Măruțescu L, Chifiriuc MC, Oniga O, Synthesis and antimicrobial activity evaluation of some new 2-(3-pyridil)-thiazolyl-1,3,4-oxadiazolines. Farmacia, 2017; 65(4): 501-507.

32. O'Toole GA, Microtiter dish biofilm formation assay. J Vis Exp., 2011; 30: 1-2.

33. Pimentaa AL, Chiaradia-Delatorre LD, Mascarello A, de Oliveira KA, Leal PC, Yunes RA, de Aguiar CBNM, Tasca CI, Nunes RJ, Smânia AJr, Synthetic organic compounds with potential for bacterial biofilm inhibition, a path for the identification of compounds interfering with quorum sensing. Int $J$ Antimicrob Agents, 2013; 42(6): 519-523.

34. Raj KK, Kumar GV, Madhuri CL, Pardhasaradhi M, Durga Lakshmi R, Ravi M, Sri Ramudu B, Venkata Rao SV, Ramachandran D, Designing of potential inhibitors against Staphylococcus aureus sortase A. J Mol Graph Model., 2015; 60: 89-97.

35. Sadekuzzaman M, Yang S, Mizan MFR, Ha SD, Current and Recent Advanced Strategies for Combating Biofilms, Compr Rev Food Sci Food Saf., 2015; 14: 491-509.

36. Schneewind O, Fowler A, Faull KF, Structure of the cell wall anchor of surface proteins in Staphylococcus aureus. Science, 1995; 268: 103-106.

37. Spirig T, Weiner EM, Clubb RT, Sortase enzymes in Gram-positive bacteria. Mol Microbiol., 2011; 82: 1044-1059.

38. Stefanska J, Nowicka G, Struga M, Szulczyk D, Koziol AE, Augustynowicz-Kopec E, Napiorkowska A, Bielenica A, Filipowski W, Filipowska A, Antimicrobial and Anti-biofilm Activity of Thiourea Derivatives Incorporating a 2-Aminothiazole Scaffold. Chem Pharm Bull., 2015; 63: 225-236.

39. Stoica CI, Marc G, Pîrnău A, Vlase L, Araniciu C, Oniga S, Palage M, Oniga O, Thiazolyl-oxadiazole derivatives targeting lanosterol $14 \alpha$-demethylase as potential antifungal agents: design, synthesis and molecular docking studies. Farmacia, 2016; 64(3): 390-397.

40. Suree N, Liew CK, Villareal VA, Thieu W, Fadeev EA, Clemens JJ, Jung ME, Clubb RT, The Structure of the Staphylococcus Aureus Sortase-Substrate Complex Reveals How the Universally Conserved LPXTG Sorting Signal Is Recognized. J Biol Chem., 2009; 284: 2446524477. 
FARMACIA, 2018, Vol. 66, 4

41. Ton-That H, Mazmanian SK, Alksne L, Schneewind O, Anchoring of Surface Proteins to the Cell Wall of Staphylococcus aureus cysteine 184 and histidine 120 of sortase form a thiolate-imidazolium ion pair for catalysis. J Biol Chem., 2002; 277(9): 7447-7452.

42. Uddin R, Lodhi MU, Combined Pharmacophore and 3D-QSAR Study on A Series of Staphylococcus aureus Sortase A inhibitors. Chem Biol Drug Design, 2012; 80: 300-314.
43. Van Acker H, Van Dijck P, Coenye T, Molecular mechanisms of antimicrobial tolerance and resistance in bacterial and fungal biofilms. Trends Microbiol., 2014; 22: 326-333.

44. Volkamer A, Kuhn D, Grombacher T, Rippmann F, Rarey M, Combining global and local measures for structure-based druggability predictions. $J$ Chem Inf Model., 2012; 52: 360-372. 